\title{
A Study on Awareness Regarding Swine Flu among Paramedical Staff of Various Private Health Care Institutions at Puducherry
}

\author{
Abhijeet Shrivastava ${ }^{1}$, V. Anebaracy ${ }^{2}$, Rimi Singh $^{3}$ \\ ${ }^{1}$ Department of Paediatrics, Sri Lakshmi Narayana Institute of Medical Sciences, Puducherry, India. ${ }^{2}$ Department of \\ Physiology, Sri Lakshmi Narayana Institute of Medical Sciences, Puducherry, India. ${ }^{3}$ Department of Obstetrics and \\ Gynaecology, Indira Gandhi Medical College and Research Institute, Puducherry, India.
}

\section{ABSTRACT}

\section{BACKGROUND}

Swine flu is causing a massive fear among the common public in India since its emergence in 2009. Influenza A H1N1 in humans can occur as mild illness or it can result in serious life-threatening complications like pneumonia, respiratory failure and death in some people. Health care professionals, who are involved in treating the swine flu affected patient, should be well aware of the symptoms of swine flu as well as precautionary measures to be followed during the treatment of the disease in order to protect themselves as well as the community. We wanted to investigate the knowledge and awareness about swine flu among paramedical staff working in various private health care institutions in Puducherry, India.

\section{METHODS}

This study was a cross sectional study, conducted among paramedical staff working in various private health care institutions at Puducherry in December 2018. 250 participants were included in the study. The participants were given predesigned questionnaire which included age, gender, occupation and their knowledge, awareness and preventive measures for swine flu.

\section{RESULTS}

$49.2 \%$ of participants knew about cough and cold symptoms. Fever, which is one of the symptoms of swine flu was known to $47.2 \%$ of swine flu participants, $20.8 \%$ of participants were aware that swine flu causes breathlessness and $100 \%$ have known about deaths due to swine flu. Regarding prevention of swine flu, wearing face mask was known to $94 \%$ of participants and $83.6 \%$ of participants had known about hand washing for prevention. $60.8 \%$ of participants had known about vaccine usage for prevention. $56.8 \%$ avoided overcrowded places and $6.8 \%$ adopted home stay in order to prevent swine flu.

\section{CONCLUSIONS}

Most of the participants of this study were very well aware about symptoms and preventive measures regarding swine flu since they are paramedical staffs presently working in different health care centers. But many studies previously conducted among common population states that the awareness regarding swine flu is very less. Hence, the government should conduct more awareness- and preventionprograms about swine flu in the community.

\section{KEY WORDS}

Awareness, Prevention, Swine Flu, Paramedical Staff
Corresponding Author:

Dr. V. Anebaracy,

Department of Physiology,

Sri Lakshmi Narayana Institute of

Medical Sciences, Puducherry, India.

E-mail: anbusuresh1976@gmail.com

DOI: $10.14260 / j e m d s / 2019 / 703$

Financial or Other Competing Interests: None.

How to Cite This Article:

Shrivastava A, Anebaracy V, Singh R. A study on awareness regarding swine flu among paramedical staffs of various private health care institutions at Puducherry. J. Evolution Med. Dent. Sci. 2019;8(43):3245-3248, $10.14260 / \mathrm{jemds} / 2019 / 703$

Submission 23-02-2019,

Peer Review 10-10-2019,

Acceptance 17-10-2019,

Published 28-10-2019.

\section{(c) $\underset{\mathrm{BY}}{\mathrm{NC}(\mathrm{NC})}$}




\section{BACKGROUND}

Swine flu is a major disease of concern nowadays because of its various strains, dreadful complications and mortality. On 11 June 2009, World health organization (WHO) raised its pandemic alert to the highest level, phase $6,{ }^{1}$ meaning that, swine flu had spread in more than two continents. On June 2010, it had caused over 18,172 deaths in more than 214 countries and overseas territories and communities. ${ }^{2}$ Most illnesses, especially the severe ones and deaths had occurred among healthy young adults. 3,4

The H1N1 subtype is pathogenic swine viral that has been documented to cause an outbreak of respiratory disease in both human and swine. The cells of the swine respiratory tract contain receptor sialyloligosaccharides possessing both $\mathrm{N}$ acetylneuraminic acid $\alpha 2,3$ galactose, which is the preferred receptor for avian influenza viruses and $\mathrm{N}$ acetylneuramic acid $\alpha 2,6$ galactose, which is the preferred receptor for mammalian influenza virus as stated by Ito et al ${ }^{5}$ and Rogers et al. 6 The typical incubation period found for influenza is 1 to 4 days, with an average of 2 to 3 days. The symptoms of influenza are sore throat, chills, severe headache, coughing, weakness and general discomfort like influenza as well as serious respiratory illness including pneumonia and respiratory failure leading to death. ${ }^{7}$

Some people are at higher risk for becoming seriously ill if they are infected with swine flu. These groups include, adults over age 65 , children under 5 years old, young adults and children under 19 years receiving long term aspirin therapy, people with compromised immune systems (due to a disease such as AIDS) and persons suffering from chronic medical conditions like Heart diseases, Diabetes, pregnant women are at higher risk for complications of swine flu. ${ }^{8}$ In India, the first case was identified on 2009 May16, in Hyderabad. ${ }^{9}$ Protection against influenza infection is conferred by neutralizing antibody for the two surface proteins, namely the hemagglutinin (HA) and the neuraminidase(NA). ${ }^{10} \mathrm{~T}$ cell immunity has been implicated in rapid clearance of influenza virus ${ }^{11 .}$ Highly immunogenic, cross-conserved epitopes can be designed by carefully overlapping conserved and immunogenic 9-mer sequences found in the influenza strains of interest. ${ }^{12}$ Inactivated influenza vaccines elicit neutralizing antibody responses that provide reasonable protection against the homologous H1N1, H3N2, and B viruses. ${ }^{13}$

Sheer volume of cases could easily overstretch already fragile and overburdened health services, especially in the developing countries, and cause considerable suffering in human population around the world. ${ }^{14}$ Late presentation at hospital and having co morbid conditions were commonly observed to be associated with poor patient prognosis. The sudden spurt of swine flu cases nowadays has made the Government unexplained but concerned. Prevention is always better than cure. Hence creating awareness about prevention, potential risks plays a very important role in controlling swine flu. Though the government is taking immediate steps and measures in controlling and managing swine flu, there are fear and myths about swine flu. Paramedical staffs play an important role in preventing and limiting the transmission of H1N1 virus to themselves as well as to patients. Mostly paramedical staffs are at a higher risk of acquiring H1N1 virus directly from the patients. Hence all paramedical staffs should be well aware of the mode of transmission as well as the preventing measures to be taken to prevent swine flu. Prevention is the most important measure to control H1N1 flu pandemic and awareness about H1N1 flu is ranked the highest in preventive measures. This study is conducted to assess the knowledge and awareness about swine flu among paramedical staffs of various private health care institutions at Puducherry.

\section{METHODS}

This study was conducted in December 2018 among the paramedical staffs working at different health care institutions at Puducherry. 250 participants were included in the study based on convenient sampling. The study protocol and procedures were approved by the Research Ethics Committee of Sri Lakshmi Narayana Institute of Medical sciences hospital, Osudu, Puducherry affiliated to Bharath University. After obtaining informed written consent from the subjects and assuring full confidentiality to the participants, data was collected. The participants were given predesigned questionnaire which included age, gender, occupation and their knowledge and awareness about the disease which included nature, mode of transmission, clinical features and preventive measures followed. Data collected was analysed by using statistical package for social science (SPSS) software program for Windows.

\section{RESULTS}

\begin{tabular}{|c|c|c|}
\hline Gender & Frequency & Percentage \\
\hline Male & 98 & $39.2 \%$ \\
\hline Female & 152 & $60.8 \%$ \\
\hline Total & $\mathbf{2 5 0}$ & $\mathbf{1 0 0} \%$ \\
\hline \multicolumn{2}{|c|}{ Table 1. Gender Distribution of Study Population } \\
\hline
\end{tabular}

\begin{tabular}{|c|c|c|}
\hline Symptoms & Frequency & Percentage \\
\hline Fever & 118 & $49.2 \%$ \\
\hline Body ache & 60 & $24.8 \%$ \\
\hline Cough and cold & 123 & $47.2 \%$ \\
\hline Breathlessness & 52 & $20.8 \%$ \\
\hline Vomiting & 82 & $32.8 \%$ \\
\hline Loose motion & 4 & $1.6 \%$ \\
\hline Headache & 34 & $13.6 \%$ \\
\hline Death & 250 & $100 \%$ \\
\hline \multicolumn{2}{|c}{ Table 2. Symptoms of Swine Flu? } \\
\end{tabular}

\begin{tabular}{|c|c|c|}
\hline Prevented by & Frequency & Percentage \\
\hline Face mask & 235 & $94 \%$ \\
\hline Handwashing & 209 & $83.6 \%$ \\
\hline Vaccine & 152 & $60.8 \%$ \\
\hline Avoiding crowded places & 142 & $56.8 \%$ \\
\hline Home stay & 92 & $6.8 \%$ \\
\hline \multicolumn{2}{|c}{ Table 3. How is Swine Flu Prevented? } \\
\hline
\end{tabular}

Study participants constituted 98 males and 152 females (Table 1).Fever, which is one of the symptom of swine flu was known to $47.2 \%$ of participants and $49.2 \%$ of participants had known about cough and cold symptoms (Table 2).20.8\% were aware that swine flu causes breathlessness and 100\% had known about deaths due to swine flu (Table 2). Regarding prevention, as found in (Table 3) wearing face mask was known to $94 \%$ of participants and hand washing for prevention of swine flu was known to $83.6 \%$ of 
participants. $60.8 \%$ of participants have known about vaccine usage for prevention. Avoiding overcrowded places and home stay in order to prevent swine flu was known to $56.8 \%$ and $6.8 \%$ of study group respectively.

\section{DISCUSSION}

The commonest known symptom of swine flu, known to most of the participants was fever (49.2\%), which was supported by the studies done by Singh et al, ${ }^{15}$ Farahat et al, ${ }^{16}$ Shilpa $K$ et al,17 Chaudhary et al. ${ }^{18}$ Next commonest symptoms known to most of the study group was cough and cold (47.2\%), which is supported by studies done by Harshal et $\mathrm{al}^{19}$ and Namrata Devi Et al. ${ }^{20} 100 \%$ of the respondents were aware that swine flu causes death which is supported by the study conducted by Sumeet Singh et al, which shows that $84.4 \%$ of the participants had known about swine flu.

$94 \%$ of participants knew about wearing face mask as a preventive measure than handwashing which was in contrast to the studies done by Farahat et al, Balkhy et al, ${ }^{21}$ Kamate et $\mathrm{al}^{22}$ and Rubin et al. ${ }^{23}$ While other studies done by Shilpa K et al, Singh et al, Suresh Rathi et $\mathrm{al}^{24}$ supports our study that wearing facemask is an effective preventive measure for swine flu. $60.8 \%$ of our study participants are aware of vaccine available for preventing swine flu since the study group are paramedical staffs who are presently working in various private institutions which is supported by the study done by Kaipa et al, ${ }^{25}$ Sumeet Singh et al. $56.8 \%$ of study population avoided crowded places which is supported by the studies done by Kamate et al and Hao HA et al. ${ }^{26}$

Whitley RJ et al ${ }^{27}$ stated that health education is an important tool to reduce prevalence of the disease. Al-Sheri et al 28 demonstrated that role of health education in modern world is increased with the goal to provide the individuals with information, skills and motivation necessary to make intelligent decisions concerning life style and personal behaviour. Adequate amounts of vaccine and antiviral are unavailable early on in a pandemic and antiviral could become ineffective because of resistance. These factors have focused attention on the use of non-pharmaceutical public health interventions such as prevention of human to human transmission. Hence, triad of knowledge, attitude and practices are all very important in preventing and controlling the mortality due to swine flu.

\section{CONCLUSIONS}

This study revealed that a high percentage of participants of the paramedical staff are very well aware of the symptoms and preventive measures regarding swine flu. Though, our study population was aware of the symptoms, prevention and treatment available for controlling swine flu, the same cannot be said about a layman in the community. The existing drawbacks of the present health sector are lack of manpower, lack of lab facilities, and lack of vaccines for tackling the swine flu pandemic. Prevention is the most appropriate measure to control H1N1 pandemic and awareness of H1N1 flu is the most important preventive measure. Proper information to the public about the H1N1 virus pandemic is important in achieving awareness with regard to potential risks and prevention of swine flu. Hence, the Government should take more steps in involving medical and paramedical people for conducting awareness- and prevention-programs among the common public. District health authorities should distribute pamphlets and install banners about the facts and myths regarding swine flu to educate common public during pandemics which are very important measures in preventing swine flu. Government should emphasize more on the vaccine to prevent this dreadful disease, which threatens each and every one of us in the community. Moreover, the public health professionals who are in close contact with the general population should be trained more about swine flu by conducting health education sessions, seminars and workshops. Advertisement regarding swine flu prevention should be displayed in public places like cinema theaters, bus stands, all government hospitals and all private hospitals.

\section{REFERENCES}

[1] Girard MP, Tam JS, Assossou OM, et al. The 2009 A (H1N1) influenza virus pandemic: a review. Vaccine 2010;28(31):4895-902.

[2] World Health Organization (WHO). Pandemic (H1N1) 2009 - Update. Disease Outbreak News (WHO), May 14, 2010.

[3] Dawood FS, Jain S, Finelli L, et al. Emergence of a novel swine-origin influenza A (H1N1) virus in humans. N Engl J Med 2009;360(25):2605-15.

[4] Center for Disease Control and Prevention (CDC). CDC advisors make recommendations for use of vaccine against novel H1N1. Press Release. Retrieved 2009.

[5] Ito T, Couceiro JN, Kelm S, et al. Molecular basis for the generation in pigs of influenza A viruses with pandemic potential. J Virol 1998;72(9):7367-73.

[6] Rogers GN, Paulson JC. Receptor determinants of human and animal influenza virus isolates: differences in receptor specificity of the $\mathrm{H} 3$ hemagglutinin based on species of origin. Virology 1983;127(2):361-73.

[7] Fotedar S, Sharma KR, Bhardwaj V, et al. Precautions in dentistry against swine flu. SRM J Res Dent Sci 2013;4(4):161-63.

[8] Prevention of Swine Influenza A (H1N1) in the dental Healthcare http://www.ct.gov/dph/lib/dph/oral health.

[9] Khanna M, Kumar P, Choudhary K, et al. Emerging Influenza virus: a global threat. J Biosci 2008;33(4):47582.

[10] Luke CJ, Subbarao K. Vaccines for pandemic influenza. Emerg Infect Dis 2006;12(1):66-72.

[11] Thomas PG, Keating R, Hulse-Post DJ, et al. Cell-mediated protection in influenza infection. Emerg Infect Dis 2006;12(1):48-54.

[12] De Groot AS, Ardito M, McClaine EM, et al. Immunoinformatic comparison of $\mathrm{T}$-cell epitopes contained in novel swine-origin influenza A (H1N1) virus with epitopes in 2008-2009 conventional influenza vaccine. Vaccine 2009;27(42):5740-7.

[13] Palese P. Making better influenza virus vaccines? Emerg Infect Dis 2006;12(1):61-5. 
[14] Swine flu India, a fight against pandemic. http://www.swinefluindia.com/. [Last cited on May 05, 2013].

[15] Singh S, Kaur P, Singh G. Study to assess the awareness, perception and myths regarding swine flu among educated common public in Patiala District. Int J Res Dev Health 2013;1(2):54-60.

[16] Farahat T, Al-Kot M, Al-Fath AO, et al. Promotion of knowledge, attitude and practice towards swine flu A/H1N1: an intervention study on secondary school children of Menofia Governorate, Egypt. Menofia Med J 2010;23:83-94

[17] Shilpa S, Kaur P, Singh G. Study to assess the awareness, perception and myths regarding swine flu among educated common public n Patiala District. Int J Res Dev Health 2013;1(2):54-60.

[18] Chaudhary V, Singh RK, Agarwal VK, et al. Awareness, perception and myths towards swine flu in school children of Bareilly, Uttar Pradesh. Indian J Public Health 2010;54(3):161-4.

[19] Kawanpure H, Ugargol AR, Padmanabha BV. A study to assess knowledge, attitude and practice regarding swine flu. Int J of Health Sciences \& Research 2014;4(8):6-11.

[20] Jhummon-Mahadnac ND, Knott J, Marshall C. A crosssectional study of pandemic influenza health literacy and the effect of a public health campaign. BMC Res Notes 2012;5:377.

[21] Balkhy HH, Abolfotouh MA, Al-Hathlool RH, et al. Awareness, attitudes and practices related to the swine influenza pandemic among the Saudi public. BMC Infect Dis 2010;10:42.
[22] Kamate SK, Agrawal A, Chaudhary H, et al. Public knowledge, attitude and behavioural changes in an Indian population during the Influenza A (H1N1) outbreak. J Infect Dev Ctries 2009;4(1):7-14.

[23] Rubin GJ, Amlot R, Page L, et al. Public perception, anxiety and behaviour change in relation to the swine flu outbreak: cross sectional telephone survey. BMJ 2009;339:2651.

[24] Rathi S, Gandhi H, Francis MR. Knowledge and awareness about H1N1 Flu in urban adult population of Vadodara, India. Electronic Physician 2011;(3):392-5. ISSN:2008-5842.

[25] Kaipa S, Epari V, Gupta S. Knowledge and attitude towards swine influenza (2009) among dental practitioners in Nellore district of Andhra Pradesh, India. J Educ Ethics Dent 2011;1(2):52-8.

[26] Hao AH, Cai YS, Feng WR, et al. Needs on information related to pandemic by the public. Zhonghua Liu Xing Bing Xue Za Zhi 2009;30(11):1117-20.

[27] Whitley RJ, Monto AS. Prevention and treatment of influenza in high risk groups: children, pregnant women, immunocompromised hosts and nursing home residents. J Infect Dis 2006;194 Suppl 2:S133-8.

[28] Al-Sheshri AS, Abdel-Fattah M, Hifnawy T. Knowledge and concern about avian influenza among secondary school students in Taif, Saudi Arabia. East Mediterr Health J 2006;(12 Suppl 2):S178-88. 